\title{
Treatment of a water treatment plant filter washing water using coagulant regenerated from the decanter sludge
}

\section{Tratamento de água de lavagem de filtro da estação de tratamento de água utilizando coagulante regenerado do lodo de decantador}

\author{
Guilherme Gavlak ${ }^{1}$; Carlos Magno de Sousa Vidal ${ }^{2}$; \\ Eduardo Ferreira Machado ${ }^{3}$
}

\begin{abstract}
Due to the high generation of waste in water treatment plants, mainly from sludge generated in decanters and from filter washing water, this study aimed to evaluate the regeneration of sludge coagulant and subsequently its use in the washing water treatment by the processes of coagulation, flocculation and sedimentation. The regeneration of the coagulant was performed through the acidic route using the methodology described by Fulton (1974), varying the time of acidification. The washing water treatment was executed in Jar Test equipment, according to the methodology presented by Di Bernardo, Di Bernardo and Centurione Filho (2002), varying the coagulant concentrations and the coagulation $\mathrm{pH}$. In the regeneration process, the aluminum concentration obtained was statistically equal in all acidification times adopted, showing that aluminum dissociation occurs in the first 10 minutes of the reaction, where an average concentration of $565.31 \mathrm{mgAl} / \mathrm{L}$ was obtained. In the washing water treatment, the best operational condition was when using a recovered coagulant dosage of $10 \mathrm{mgAl} / \mathrm{L}$ and coagulation $\mathrm{pH} 7$, obtaining a removal $\geq 80 \%$ of the solids, aluminum, iron, manganese, turbidity and color apparent, and about $99 \%$ of the evaluated faecal contamination indicators.
\end{abstract}

Keywords: Water treatment plants sludge. Filter washing water. Coagulant regeneration. Acid road. Water treatment wastes.

\section{Resumo}

Devido a elevada geração de resíduos nas estações de tratamento de água, principalmente dos lodos gerados nos decantadores (LETA) e das águas de lavagem dos filtros (ALF), o presente estudo teve como objetivo avaliar a regeneração de coagulante do LETA e posteriormente utilizá-lo no tratamento da ALF pelos processos de coagulação, floculação e sedimentação. A regeneração do coagulante foi realizada por via ácida mediante a metodologia descrita por Fulton (1974), variando o tempo de acidificação. O tratamento da ALF foi efetuado em equipamento Jar Test, conforme a metodologia apresentada por Di Bernardo, Di Bernardo e Centurione Filho (2002), variando as concentrações do coagulante e o pH de coagulação. No processo de regeneração, a concentração de alumínio obtida mostrou-se igual do ponto de vista estatístico em todos os tempos de acidificação adotados, mostrando que a dissociação do alumínio acontece nos primeiros 10 minutos da reação, onde obteve-se uma concentração média $565,31 \mathrm{mgAl} / \mathrm{L}$. No tratamento da ALF, a melhor condição operacional foi quando utilizado a dosagem $10 \mathrm{mgAl} / \mathrm{L}$ de coagulante recuperado em $\mathrm{pH}$ 7 de coagulação, obtendo-se uma remoção $\geq 80 \%$ de grande parte dos sólidos, alumínio, ferro, manganês, turbidez e cor aparente, e cerca de $99 \%$ dos indicadores de contaminação fecal avaliados.

Palavras-chave: Lodo da estação de tratamento de água. Água de lavagem de filtro. Regeneração de coagulante. Via ácida. Resíduos do tratamento de água.

\footnotetext{
${ }^{1}$ PhD Student., Postgraduate Program Forest Science, UNICENTRO, Irati, PR, Brazil; E-mail: eng.guilhermegavlak@gmail.com

${ }^{2}$ Dr. Prof., Dept. Sanitary and Environmental Engineering, UNICENTRO/PR, Irati, PR, Brazil; E-mail: cmsvidal@ unicentro.br

${ }^{3}$ Environmental Engineering Student, UNICENTRO/PR, Irati, PR, Brazil. E-mail: eduardofmachado96@gmail.com
} 


\section{Introduction}

Most of the water treatment plants (WTP) in Brazil are composed of a complete cycle system, which is basically formed by the processes of coagulation, flocculation, sedimentation, filtration, disinfection, $\mathrm{pH}$ correction and fluoridation. Considering that this type of treatment system is commonly used due to the fact that it complies with the water quality standards required for potability, established by Ministry of Health order 2.914 (BRASIL, 2011).

This type of system is responsible for the generation of wastes, such as the filter washing water and the sludge generated in the water treatment stations decanters. According to Di Bernardo and Dantas (2005), these are classified as waste generated directly in the treatment process itself and their volumes are between 2 to $10 \%$ of the total volume of treated water (USEPA, 2002; RAJ et al., 2008).

The production and formation of these wastes at the WTP are directly influenced by the quality of the water collected from rivers and water sources, as well as by the treatment methods used. Therefore, the characteristics of raw water will indicate the filter washing type and frequency, as well as the removal of the sludge from the bottom of the decanters, mainly due to the amount of solids present in it Di Bernardo and Dantas (2005), Di Bernardo, Scalize and Souza Filho (1999) and Slavik, Jehmlich and Uhl (2013). Among these large volumes of waste generated, according to IBGE (2002), about $73 \%$ of these are dumped into water bodies, affecting the quality of the water in the environment, as well as the present biodiversity. Irregular discharges of these residues into water bodies are responsible for several impacts on the environment, which is mainly due to the high levels of solids and metals, resulting in several problems in the aquatic ecosystem. Among the main environmental problems, the siltation of these sites through the formation of sludge banks, as well as the accumulation of highly toxic compounds, as in the case of heavy metals and the increase in the concentrations of microorganisms (CORDEIRO, 1999; DI BERNARDO; DANTAS, 2005).

Regarding the filter washing water, it is generated from the insertion of water with high pressure and speed into the filters in a contrary flow, called ascent flow washing, these most commonly used in full cycle WTP that uses descending filters in their treatment processes. At this stage, the particles retained in the bed are released and remain in the wash water, consequently, the washing water is composed of high concentrations of solids, chemical oxygen demand (COD), metals such as aluminum, iron and manganese, organic material, and especially pathogenic microorganisms.

The sludge is generated in the treatment plants decanters, after the coagulation, flocculation and sedimentation processes, they are mainly composed of hydroxides which represent about 35 to $50 \%$ of the solids present in it (BISHOP, 1987), as well of organic material, solids in general, pathogenic microorganisms and other organic and inorganic compounds. In addition, they are made up of metals such as aluminum, copper, iron, manganese and others (USEPA, 2011). The sludges from this type of process, when using coagulants containing aluminum and iron, have some characteristics that can make their treatment process difficult, such as a reduced compaction capacity and more liquid, gelatinous and pasty aspects (DI BERNARDO; DANTAS; VOLTAN, 2012).

The most common sludge and washing water destination is their recirculation in the treatment plant itself, however, this process can cause several problems. Among the main recirculation obstacles, it can increase the concentrations of metals such as iron and manganese, total organic carbon, microorganisms such as protozoa, Escherichia coli, total and thermotolerant coliforms (BRAGA et al., 2006; BOURGEOIS; WALSH; GAGNON, 2004; CORNWELL; LEE, 1994) in the liquid mass to be treated. According to McCormick, Porter and Walsh (2010), the recirculation of large volumes of washing water into the system can favor the formation of other products such as trihalomethanes and haloacetic acids, which are considered carcinogenic and toxic compounds that appear from disinfection processes with chlorine in the presence of organic material, where the authors do not recommend recirculation of more than $10 \%$ of this waste.

One of the methods of reducing the WTP sludge polluting potential and the problems generated in treatment plants is the regeneration of the coagulant present in it. This coagulant recovery enables the reduction of the volume of sludge to be treated later, as well as reducing its polluting potential by removing the coagulant present in it, this process also enables its reuse in future water treatment processes (GONÇALVES; BRANDÃO; BARRETO, 1999). Several studies of coagulant regeneration are developed, for example, by the acid route, which is among the others showing greater progress and applicability (AHMAD et al., 2016; DI BERNARDO; DANTAS; VOLTAN, 2012; FREITAS; FERREIRA FILHO; 
PIVELI, 2005; GONÇALVES; BRANDÃO; BARRETO, 1999; KEELEY; JARVIS; JUDD, 2014; OKUDA et al., 2014). Therefore, the present study aimed to evaluate the regeneration of the coagulant existing in the sludge of the water treatment plant decanter using an acid route at different times of acidification, as well as its efficiency in the treatment of filter washing water by coagulation, flocculation and sedimentation under different operating conditions.

\section{Materials and Methods}

The research was carried out on a bench scale, by collecting sludge from the decanter and filter washing water from a full scale WTP, which operates in a full cycle and uses the polyaluminum chloride (PAC) coagulant in its process of treatment.

\section{Decanter sludge coagulant recovery}

First, the WTP sludge was collected, which was later characterized according to the parameters present in Table 1, according to the procedures indicated in the Standard Methods for the Examination of Water and Wastewater 23rd edition (APHA, 2017).

After the characterization of WTP sludge, the process of regeneration by acidic method of the coagulant present in the sludge was used in Jar Test equipment, following the method of Fulton (1974). The acidification of the sludge was carried out with the addition of sulfuric acid $\left(\mathrm{H}_{2} \mathrm{SO}_{4}\right)$ under the operating conditions contemplated in Table 2.

The Jar Test jars were filled with 2 liters of WTP sludge previously homogenized and then fixed at a $\mathrm{pH}$ equal to 2 , these remained for the predetermined periods in the evaluated mixing times, as according to Asce (1996), Saunders and Roeder (1991) and Masschelein, Devleminck and Genot (1985), time is one of the factors that most influence the coagulant recovery process. The tests performed were performed in triplicate.

After the mixing period and the solids sedimentation time related to their sedimentation speed, supernatant samples were collected from each jar with their specific mixing times, this being the regenerated coagulant. Subsequently, analyzes of the aluminum (Al) concentration in the samples were made.

To interpret the data obtained in the experiments, statistical analysis was performed using ASSISTAT software Version 7.7 pt. (SILVA, 2017). First, the Bartlett test was applied in order to verify the homogeneity of the data, then the analysis of variance (ANOVA) between the means of treatments with a significance of $95 \%$ was performed. After obtaining the optimal operational, the process was repeated adopting this condition so that a greater amount of recovered coagulant was obtained to carry out the subsequent filter washing water treatment experiments.

\section{Filter washing water treatment}

The collected filter washing water was first characterized according to the parameters presented in Table 3. The procedures used to perform the analyzes were those indicated in the Standard Methods for the Examination of Water and Wastewater (APHA, 2017; CETESB, 1990).

After the characterization of the Filter Washing Water, the process of treatment by coagulation, flocculation and sedimentation began, using the regenerated coagulant from WTP sludge according to the methodology presented by Di Bernardo, Di Bernardo and Centurione Filho (2002). This procedure was performed in a Jar Test equipment and in triplicate. The experiment was governed by the operating conditions presented in Table 4.

After obtaining the data, statistical treatment was put through using the ASSISTAT Version 7.7 pt. software, in order to obtain the best operational condition for the treatment of filter washing water using the recovered coagulant. For this procedure, the Bartlett test was performed, followed by the analysis of variance (ANOVA), when verifying the statistical difference between the treatments, the Tukey test was subsequently applied $(\alpha=0.05)$.

\section{Results and discussion}

\section{Coagulant recovery}

The characterization of the WTP sludge used in this research is shown in Table 5:

WTP sludge, in addition to being classified as solid waste and having the need for its management in a way to guarantee the premises of the National Solid Waste Policy (BRASIL, 2010), it has high concentrations of various parameters as shown in Table 5.

High concentrations of COD are directly related to the presence of organic material. These are responsible for several environmental impacts on water bodies, such as the reduction of dissolved oxygen in the environment, from its consumption by aerobic microorganisms responsible for the degradation of the organic matter, causing negative impacts on biodiversity. 
Table 1 - Control variables for the characterization of the WTP settling tank sludge.

\begin{tabular}{cc}
\hline Parameters & Methods \\
\hline $\mathrm{pH}$ & Potentiometric \\
Chemical Oxygen Demand (COD) $(\mathrm{mg} / \mathrm{L})$ & UV-Vis spectrophotometry \\
Total Solids (TS) $(\mathrm{mg} / \mathrm{L})$ & Gravimetric \\
Total Volatile Solids (TVS) $(\mathrm{mg} / \mathrm{L})$ & Gravimetric \\
Total Fixed Solids (TFS) $(\mathrm{mg} / \mathrm{L})$ & Gravimetric \\
Total Dissolved Solids (TDS) $(\mathrm{mg} / \mathrm{L})$ & Gravimetric \\
Aluminum (Al) $(\mathrm{mg} / \mathrm{L})$ & Flame atomic absorption \\
Total Iron $(\mathrm{Fe})(\mathrm{mg} / \mathrm{L})$ & UV-Vis spectrophotometry \\
Manganese $(\mathrm{Mn})(\mathrm{mg} / \mathrm{L})$ & UV-Vis spectrophotometry \\
\hline
\end{tabular}

Source: The authors.

Table 2 - Operational conditions for recovery of coagulant from WTP sludge.

\begin{tabular}{cc}
\hline Control Variables & Conditions \\
\hline Acidification $\mathrm{pH}$ & 2 \\
Mixing gradient $(\mathrm{RPM})$ & 150 \\
Mixing time $(\mathrm{min})$ & $10,30,60,120$ and 1440 \\
Sedimentation speed $(\mathrm{cm} / \mathrm{min})$ & 0.2 \\
\hline
\end{tabular}

Source: The authors.

Regarding the high contents of all kinds of solids found in WTP sludge, when this is erroneously disposed in water bodies, they are responsible for the increase in its color and turbidity, reducing its euphotic zone, which affects the photosynthetic processes. Another factor favored by the excess of solids is the siltation of river beds due to its sedimentation, therefore, the depth in these places is reduced and it causes the growth of sand banks and mud.

The high presence of metals such as iron and manganese in this type of waste are also responsible for several environmental impacts on water bodies, which are even more aggravated when they are associated with organic material. Considering that iron is transformed into organic and can be oxidized to colloidal iron through the formation of ferric hydroxide, giving a reddish color to the water (ARAÚJO et al., 2016). In addition, ferrous salts have a high solubility in water, however, they are easily oxidized, resulting in iron hydroxides, which precipitate and help to form the sludge banks and favor the siltation of water bodies, as in the case of manganese. In view of the facts presented, it is extremely important to correctly manage WTP sludge, in order to avoid various impacts related to this type of waste.

After carrying out the coagulant regeneration processes through the acidic route of WTP sludge, the aluminum concentrations were obtained at each reaction time adopted, as shown in Figure 1.
Figure 1 - Aluminum concentrations in the regenerated coagulant related to the predetermined acidification times.

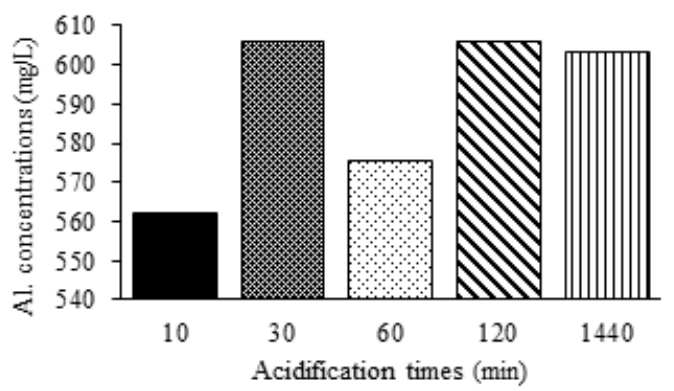

Source: The authors.

Through the statistical treatment of the obtained data, it was found that the regeneration of the coagulant at different acidification times was statistically equal, therefore, the aluminum concentrations obtained in the supernatant do not differ from each other when time is increased. Therefore, the 10-minute acidification time was adopted as the optimal operational time for coagulant regeneration, being the smallest among the others, which facilitates the process and makes it more viable on a full scale. This time is reported in the literature by Freitas, Ferreira Filho and Piveli (2005), as the best time for aluminum regeneration, when carrying out the coagulant regeneration process present in the WTS sludge, at an acidification $\mathrm{pH}$ between 2 and 3 , which uses aluminum sulphate and ferric sulphate as coagulants.

From the regeneration process using 10 minutes as mixing time in the acidification, about 1.4 liters of regenerated coagulant was obtained for every 2 liters of WTP sludge used, and an average aluminum concentration equal to $562.35 \pm 6,11 \mathrm{mg} / \mathrm{L}$, which is a significant value, since Weber and Torres (2007) in their studies carried out at the WTP Pintagui obtained about $103.62 \mathrm{mg} / \mathrm{L}$ of $\mathrm{Al}$. However, different coagulant dosages used in WTP can influence in the results. 
Table 3 - Parameters used for filter washing water characterization.

\begin{tabular}{|c|c|}
\hline Parameters & Methods \\
\hline $\mathrm{pH}$ & Potentiometric \\
\hline Chemical Oxygen Demand (COD) (mg/L) & UV-Vis spectrophotometry \\
\hline Total Solids $(\mathrm{TS})(\mathrm{mg} / \mathrm{L})$ & Gravimetric \\
\hline Total Volatile Solids (TVS) (mg/L) & Gravimetric \\
\hline Total Fixed Solids (TFS) (mg/L) & Gravimetric \\
\hline Total Dissolved Solids (TDS) (mg/L) & Gravimetric \\
\hline Total Suspended Solids (TSS) (mg/L) & Gravimetric \\
\hline Volatile Suspended Solids (VSS) (mg/L) & Gravimetric \\
\hline Fixed Suspended Solids (FSS) (mg/L) & Gravimetric \\
\hline Sedimentable Solids (SS) (ml/L) & Imhoff cone \\
\hline Aluminum (Al) (mg/L) & Flame atomic absorption \\
\hline Total Iron $(\mathrm{Fe})(\mathrm{mg} / \mathrm{L})$ & UV-Vis spectrophotometry \\
\hline Manganese (Mn) (mg/L) & UV-Vis spectrophotometry \\
\hline Electrical conductivity $(\mathrm{EC})(\mu \mathrm{S} / \mathrm{cm})$ & Potentiometric \\
\hline Temperature $(\mathrm{T})\left({ }^{\circ} \mathrm{C}\right)$ & Thermometer \\
\hline Turbidity (uT) & Turbidimetric \\
\hline Apparent color (uC) & UV-Vis spectrophotometry \\
\hline True color (uC) & UV-Vis spectrophotometry \\
\hline Alkalinity $\left(\mathrm{mg} / \mathrm{LCaCO}_{3}\right)$ & Titrimetric \\
\hline Hardness $\left(\mathrm{mg} / \mathrm{LCaCO}_{3}\right)$ & Titrimetric \\
\hline Coliphages (UFP/100ml) & Plate count \\
\hline Total coliforms (CFU/100ml) & Filter membranes \\
\hline Escherichia Coli (CFU/100ml) & Filter membranes \\
\hline
\end{tabular}

Source: The authors.

Table 4 - Filter washing water treatment tests operational conditions.

\begin{tabular}{cc}
\hline Control variables & Conditions \\
\hline Coagulant dosage $(\mathrm{mgAl} / \mathrm{L})$ & $10,20,30,40$ and 50 \\
Coagulation $\mathrm{pH}$ & 5,7 and 9 \\
Rapid mixing gradient $\left(\mathrm{s}^{-1}\right)$ & 500 \\
Rapid mixing time $(\mathrm{s})$ & 30 \\
Slow mixing gradient $\left(\mathrm{s}^{-1}\right)$ & 40 \\
Slow mixing time $(\mathrm{min})$ & 20 \\
Sedimentation speed $(\mathrm{cm} / \mathrm{min})$ & 0.2 \\
\hline
\end{tabular}

Source: The authors.

Table 5 - Characterization of treatment plant decanter sludge.

\begin{tabular}{cc}
\hline Parameters & Medium values \\
\hline $\mathrm{pH}$ & $7 \pm 0.07$ \\
COD $(\mathrm{mg} / \mathrm{L})$ & $1523 \pm 2.05$ \\
Total Solids $(\mathrm{mg} / \mathrm{L})$ & $11290 \pm 3.39$ \\
Total Volatile Solids $(\mathrm{mg} / \mathrm{L})$ & $2691 \pm 1.35$ \\
Total Fixed Solids $(\mathrm{mg} / \mathrm{L})$ & $8599 \pm 0.47$ \\
Total Dissolved Solids $(\mathrm{mg} / \mathrm{L})$ & $1240 \pm 2.09$ \\
Aluminum $(\mathrm{mg} / \mathrm{L})$ & $1.65 \pm 0.00$ \\
Total Iron $(\mathrm{mg} / \mathrm{L})$ & $218.33 \pm 1.24$ \\
Manganese $(\mathrm{mg} / \mathrm{L})$ & $20.26 \pm 0.71$ \\
\hline
\end{tabular}

Source: The authors.
In the studies made by Julio et al. (2010), when evaluating the coagulant recovery in an WTP which uses the polyaluminum chloride in its coagulation process, the authors obtained an aluminum concentration equal to $130 \mathrm{mg} / \mathrm{L}$ in the supernatant after the regeneration process. For this process, the $\mathrm{pH}$ was maintained between 1.5 and 2.0 for a period of 10 minutes with agitation of $185 \mathrm{~s}^{-1}$ and later, a period of 20 minutes for sedimentation.

In studies carried out by Jung et al. (2016), performing the sludge of decanter regeneration process from the WTP that uses polyaluminum chloride as coagulant, the authors obtained a recovery of $99.5 \%$ of the aluminum present. Besides, in studies Bishop (1987) using a sludge generated from coagulation using aluminum sulfate, recovery of 2000 and $2700 \mathrm{mg} / \mathrm{L}$ was obtained. Therefore, it is stated that, in the regeneration process, the highest concentration of aluminum ends up in the regenerated coagulant, however, the concentration of aluminum present in WTP sludge is reduced (JULIO et al., 2010) such as its polluting potential.

The characterization of the collected filter washing water containing the mean values for each variable evaluated is presented in Table 6 . 
Table 6 - Filter washing water characterization collected at the WTP.

\begin{tabular}{cc}
\hline Control variables & Medium values \\
\hline $\mathrm{pH}$ & $7.1 \pm 0.0$ \\
COD $(\mathrm{mg} / \mathrm{L})$ & $132 \pm 4.08$ \\
Total Solids $(\mathrm{mg} / \mathrm{L})$ & $560 \pm 1.87$ \\
Total Volatile Solids $(\mathrm{mg} / \mathrm{L})$ & $136 \pm 2.23$ \\
Total Fixed Solids $(\mathrm{mg} / \mathrm{L})$ & $424 \pm 1.98$ \\
Total Dissolved Solids $(\mathrm{mg} / \mathrm{L})$ & $48 \pm 1.74$ \\
Total suspended solids $(\mathrm{mg} / \mathrm{L})$ & $512 \pm 2.21$ \\
Volatile suspended solids $(\mathrm{mg} / \mathrm{L})$ & $90 \pm 1.17$ \\
Fixed suspended solids $(\mathrm{mg} / \mathrm{L})$ & $470 \pm 1.78$ \\
Settleable solids $(\mathrm{ml} / \mathrm{L})$ & $43 \pm 0.09$ \\
Aluminum $(\mathrm{mg} / \mathrm{L})$ & $50 \pm 0$ \\
Total Iron $(\mathrm{mg} / \mathrm{L})$ & $19.83 \pm 0.62$ \\
Manganese $(\mathrm{mg} / \mathrm{L})$ & $1.1 \pm 0.11$ \\
Electrical conductivity $(\mu \mathrm{S} / \mathrm{cm})$ & $76.16 \pm 0.18$ \\
Temperature $\left({ }^{\circ} \mathrm{C}\right)$ & $17 \pm 0.07$ \\
Turbidity $(\mathrm{uT})$ & $406 \pm 3.68$ \\
Apparent color $(\mathrm{uC})$ & $3598 \pm 6.34$ \\
True color $(\mathrm{uC})$ & $9 \pm 1.24$ \\
Alkalinity $\left(\mathrm{mg} / \mathrm{LCaCO}{ }_{3}\right)$ & $45.33 \pm 0.23$ \\
Hardness $\left(\mathrm{mg} / \mathrm{LCaCO}{ }_{3}\right)$ & $31.87 \pm 1.80$ \\
Coliphages $(\mathrm{UFP} / 100 \mathrm{ml})$ & $0 \pm 0$ \\
Total coliforms $(\mathrm{CFU} / 100 \mathrm{ml})$ & $23200 \pm 49.5$ \\
Escherichia Coli $(\mathrm{CFU} / 100 \mathrm{ml})$ & $3400 \pm 25.98$ \\
\hline
\end{tabular}

Source: The authors.

It can be observed in the characterization of the crude filter washing water present in Table 6, concentrations above the allowed for release into water bodies in relation to the solids present, mainly the se dimentable ones, which is described in RESOLUTION No. 430 of May 13th, 2011, which complements and amends Resolution No. 357 of 2005 and cannot exceed $1 \mathrm{ml} / \mathrm{L}$, as well as in relation to iron and manganese, which exceed the maximum permitted values of 15.0 and $1.0 \mathrm{mg} / \mathrm{L}$, respectively (CONAMA, 2011).

The environmental problems related to this type of effluent when released indiscriminately into water bodies are diverse. In addition to those already reported due to the WTP sludge that has high concentrations of COD, metals such as iron and manganese and the high solids contents, the filter washing water has large amounts of microorganisms which can generate operational problems in the WTP, considering that it is mostly recirculated in the system and contaminates the entire treated liquid mass.

The performance of the recovered coagulant in the treatment by coagulation, flocculation and sedimentation of the washing water was evaluated, having as control variables for obtaining the operational optimum the re- maining turbidity, apparent color and true color and the $\mathrm{pH}$ resulting from the treatment, and the results obtained are present in Figures 2-5.

Figure 2 - Post-treatment filter wash water remaining turbidit.

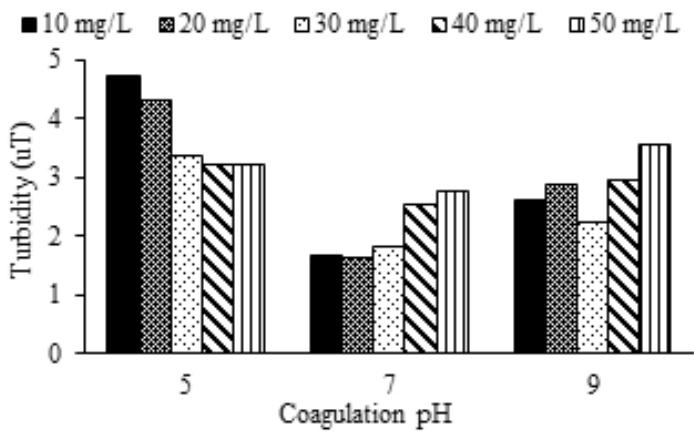

Source: The authors.

By analyzing Figure 2, it is verified that the values obtained for remaining turbidity did not exceed 5uT, which is the maximum acceptable value for potability purposes according to Ordinance GM/MS No. 888, May 4th, 2021, therefore, in case of recirculation, would not change the treated water quality. Through the statistical treatment of the data, there is a statistical difference between them and through the Tukey test, it is concluded with $95 \%$ confidence, that when using the dosages of 10,20 and $30 \mathrm{mg} / \mathrm{L}$ at $\mathrm{pH} 7$ of coagulation had the best efficiencies for turbidity removal, being these statistically equal and standing out among the other conditions tested.

Figure 3 - Post-treatment filter washing water remaining apparent color.

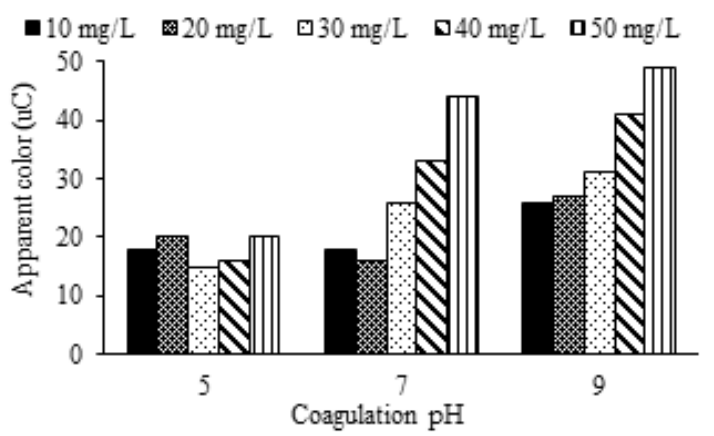

Source: The authors.

In Figure 3, there is a proximity between the lowest average values obtained for the remaining apparent color for the conditions evaluated, which is corroborated by the Tukey test, where it proves that the dosages of 10, 20, 30,40 and $50 \mathrm{mg} / \mathrm{L}$ at $\mathrm{pH} 5$ of coagulation, as well as 10 and $20 \mathrm{mg} / \mathrm{L}$ at $\mathrm{pH} 7$ and 9 do not have significant difference in function of the apparent color values in the treated effluent, therefore, they are considered statistically equal. 
Figure 4 - Remnant post-treatment filter washing water true color.

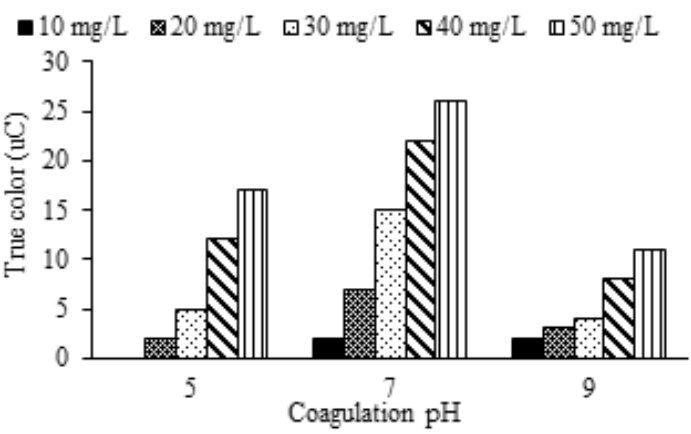

Source: The authors.

By the Figure 4 analysis, it is verified that the lowest levels of true color, therefore, the best reductions, were obtained under the conditions of $10 \mathrm{mg} / \mathrm{L}$ at $\mathrm{pH} 5,7$ and 9 , as well as, when using the dosage of $20 \mathrm{mg} / \mathrm{L}$ at coagulation $\mathrm{pH} 5$ and 9. This statement is supported by Tukey's statistical test, where it is proven with $95 \%$ confidence that they are classified as equal.

Figure 5- pH values resulting from post-treatment filter wash water.

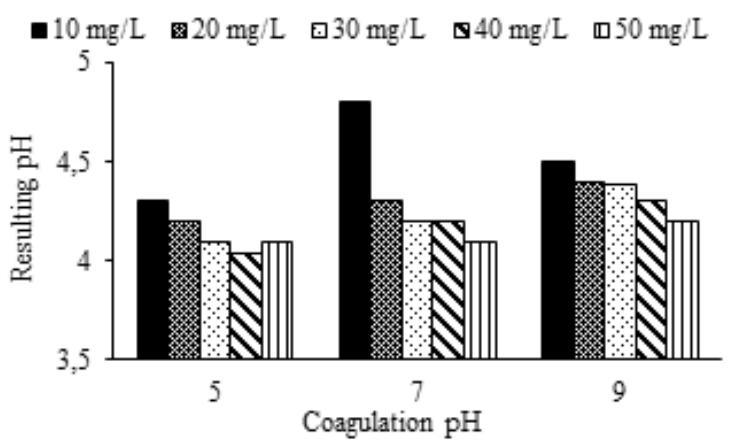

Source: The authors.

Regarding the resulting $\mathrm{pH}$ after the proposed treatments, it is noted that in all operating conditions adopted there was a decay of the $\mathrm{pH}$ in relation to "crude". This occurs due to the release of $\mathrm{H}^{+}$protons in the reaction

$13 \mathrm{Al}^{3+}+28 \mathrm{H}_{2} \mathrm{O} \rightarrow \mathrm{Al}_{13} \mathrm{O}_{4}(\mathrm{OH})_{24}^{7+}-32 \mathrm{H}^{+} \log \mathrm{K}=97$,

which consumes the substances responsible por generating alkalinity, and promotes the release of $\mathrm{CO}_{2}$, therefore, reduces the $\mathrm{pH}$ of the medium (DI BERNARDO; DANTAS, 2005). When analyzing graphically, there is greater proximity of neutrality ( $\mathrm{pH} 7$ ) when using the dosage of 10 $\mathrm{mg} / \mathrm{L}$ at $\mathrm{pH} 7$ of coagulation, which is proven by statistical tests.

Through the treatment of obtained data through statistical analyses, it was adopted as operational optimum for the treatment by coagulation, flocculation and sedimentation of filter washing water, using the coagulant regenerated from WTP sludge, the dosage of $10 \mathrm{mg} / \mathrm{L}$ at
$\mathrm{pH} 7$ of coagulation. Even though this condition has been shown to be statistically equal to the others in the removal of some parameters, it was adopted due to the fact that it does not require chemical products to correct the $\mathrm{pH}$ of the pre-treatment filter washing water. Therefore, it does not need the operational handling of acids and bases, combined with the fact that it uses the lowest dosage of recovered coagulant among the others studied, making the process less dangerous, more economical and viable on a full scale.

After obtaining the optimal operational, the filter washing water was characterized after treatment by coagulation/flocculation/sedimentation in the optimized condition, the results are shown in Table 7.

Table 7 - Post-treatment filter washing water characterization using $10 \mathrm{mgAl} / \mathrm{L}$

\begin{tabular}{cc}
\hline Control variables & Medium values \\
\hline $\mathrm{pH}$ & $4.7 \pm 0.14$ \\
COD $(\mathrm{mg} / \mathrm{L})$ & $57 \pm 1.24$ \\
Total Solids $(\mathrm{mg} / \mathrm{L})$ & $184 \pm 0.94$ \\
Total Volatile Solids $(\mathrm{mg} / \mathrm{L})$ & $75 \pm 1.01$ \\
Total Fixed Solids $(\mathrm{mg} / \mathrm{L})$ & $109 \pm 0.91$ \\
Total Dissolved Solids $(\mathrm{mg} / \mathrm{L})$ & $179 \pm 1.98$ \\
Total suspended solids $(\mathrm{mg} / \mathrm{L})$ & $4 \pm 0.89$ \\
Volatile suspended solids $(\mathrm{mg} / \mathrm{L})$ & $2 \pm 0.68$ \\
Fixed suspended solids $(\mathrm{mg} / \mathrm{L})$ & $2 \pm 0.76$ \\
Settleable solids $(\mathrm{ml} / \mathrm{L})$ & $0 \pm 0$ \\
Aluminum $(\mathrm{mg} / \mathrm{L})$ & $10 \pm 0$ \\
Total Iron $(\mathrm{mg} / \mathrm{L})$ & $0.33 \pm 0.04$ \\
Manganese $(\mathrm{mg} / \mathrm{L})$ & $0.044 \pm 0.00$ \\
Electrical conductivity $(\mu \mathrm{S} / \mathrm{cm})$ & $116 \pm 0.10$ \\
Temperature $\left({ }^{\circ} \mathrm{C}\right)$ & $17 \pm 0.06$ \\
Turbidity $(\mathrm{uT})$ & $2.38 \pm 0.26$ \\
Apparent color $(\mathrm{uC})$ & $18 \pm 2.05$ \\
True color $(\mathrm{uC})$ & $4 \pm 0.47$ \\
Alkalinity $(\mathrm{mg} / \mathrm{LCaCO}$ & $0 \pm 0$ \\
Hardness $(\mathrm{mg} / \mathrm{LCaCO}$ & \\
Coliphages $(\mathrm{UFP} / 100 \mathrm{ml})$ & $28.86 \pm 3.72$ \\
Total coliforms $(\mathrm{CFU} / 100 \mathrm{ml})$ & $0 \pm 0$ \\
Escherichia Coli $(\mathrm{CFU} / 100 \mathrm{ml})$ & $7 \pm 2.49$ \\
\hline
\end{tabular}

Source: The authors.

Through the characterization of the post-treatment filter washing water, there is a significant reduction in the physical, chemical and biological parameters present in it.

When evaluating the efficiency in removing chemical oxygen demand, the average value obtained for it was equal to $56.84 \%$, resulting in an average concentration of $57 \mathrm{mg} / \mathrm{L}$. The efficiency obtained was not so significant due to the use of coagulant, considering that part of it ends up being dissolved in the treated effluent. 
The large reductions in total suspended solids, volatile suspended solids, fixed suspended solids, settleable solids, metals such as aluminum, iron and manganese, turbidity and apparent color are highlighted, which had a decrease of $\geq 80 \%$ with the use of this system of treatment. Another point to be highlighted is the removal of over $99 \%$ of total coliforms and Escherichia Coli, since these microorganisms are one of the major problems related to this type of effluent. Considering that in most cases the filter washing water is recirculated to the treatment system and this can cause a series of problems for the operation of the WTP and the quality of the treated water, mainly due to the increase in the concentration of pathogenic microorganisms that can compromise public health (CORDEIRO, 1999; REISSMANN; UHL, 2006), the high removal obtained from the experiment has great significance in reducing the related risks.

\section{Conclusions}

Based on the presented facts, it is concluded that the aluminum concentration in the acidic regeneration process of the coagulant present in WTP sludge does not vary according to the evaluated acidification times. Therefore, most of the aluminum present dissociates from solids in the first 10 minutes of the process, this time being considered the ideal among the others for regeneration, as it makes the process less time-consuming and costly.

In addition, it is stated that the best condition, among the others studied, for the treatment of filter washing water by coagulation, flocculation and sedimentation using regenerated decanter sludge coagulant related to the evaluated parameters, is when using the concentration of $10 \mathrm{mg} / \mathrm{L}$ aluminum coagulant at $\mathrm{pH} 7$ of coagulation, significantly reducing its polluting potential.

\section{References}

AHMAD, T.; AHMAD, K.; AHAD, A.; ALAM, M. Characterization of water treatment sludge and its reuse as coagulant. Journal of Environmental Management, London, v. 182, p. 606-611, 2016.

APHA - AMERICAN PUBLIC HEALTH ASSOCIATION. Standard methods for the examination of water and wastewater. 23rd ed. Washington: Apha, 2017.
ARAÚJO, G. V. R.; BARBOSA, I. M. B. R.; ARAÚJO, A. V. R.; TAVARES, R. G.; SILVA, R. C. P. Avaliação do teor de ferro dos principais sistemas de abastecimento de água da RMR/PE. In: CONGRESSO BRASILEIRO DE GESTÃO AMBIENTAL, 7., 2016, Campina Grande. Anais [...]. Campina Grande: [s. n.], 2016.

\section{ASCE - AMERICAN SOCIETY OF CIVIL ENGI-} NEERS. Management of water treatment plant residuals. New York: ASCE; AWWA, 1996.

BISHOP, S. L. Alternate processes for treatment of water plant wastes. Journal AWWA, Denver, p. 503-506, 1987. Available from: <https://www.jstor.org/stable/4126949 9>. Access in: June 25, 2021.

BOURGEOIS, J. C.; WALSH, M. E.; GAGNON, G. A. Comparison of process options for treatment of water treatment residual streams. Journal of Environmental Engineering and Science, London, v. 3, n. 6, p. 477-484, 2004.

BRAGA, M. D.; BEVILACQUA, P. D.; BASTOS, R. K.; FREITAS, A. G.; FERREIRA, G. M. Caracterização microbiológica da água de lavagem de filtros e avaliação de diferentes cenários de recirculação. AIDIS, Coyoacán, v. 1, n. 3, p. 1-13, 2006.

BRASIL. Lei $n^{o} 12.305$ de agosto de 2010. Institui a Política Nacional de Resíduos Sólidos, altera a Lei $\mathrm{n}^{\circ}$ 9.605, de 12 de fevereiro de 1998 e dá outras providências. Brasília: Presidência da República, 2010.

BRASIL. Ministério da Saúde. Portaria $n^{o} 2.914$, de 12 de dezembro de 2011. Dispõe sobre os procedimentos de controle e de vigilância da qualidade da água para consumo humano e seu padrão de potabilidade. Brasília: MEC, 2011.

CETESB - COMPANHIA AMBIENTAL DO ESTADO DE SÃO PAULO. L5.225 Determinação de colifagos em amostras de água: método de ensaio. São Paulo: Cetesb, 1990.

CONAMA - CONSELHO NACIONAL DO MEIO AMBIENTE. Resolução $n^{\circ} 430$ de 13 de maio de 2011. Dispõe sobre as condições e padrões de lançamento de efluentes, complementa e altera a Resolução no 357, de 17 de março de 2005, do Conselho Nacional do Meio AmbienteCONAMA. Brasília: Conama, 2011. 
CORDEIRO, J. S. Importância do tratamento de disposição adequada de lodos de ETAs. In: REALI, M. A. P. (coord.). Noções gerais de tratamento e disposição de lodos de estações de tratamento de água. Rio de Janeiro: ABES, 1999. cap. 1.

CORNWELL, D. A.; LEE, R. G. Waste stream recycling: its effect on water quality. Journal American Water Works Association, Denver, v. 86, n. 11, p. 50-63, 1994.

DI BERNARDO, L.; DI BERNARDO, A.; CENTURIONE FILHO, P. Ç. Ensaios de tratabilidade de água e dos resíduos gerados em estações de tratamento de água. São Carlos: Editora Rima, 2002.

DI BERNARDO, L.; DANTAS, A. D. B. Métodos e técnicas de tratamento de água. 2. ed. São Carlos: Rima, 2005. $792 \mathrm{p}$.

DI BERNARDO, L.; DANTAS, A. D. B.; VOLTAN, P. E. N. Métodos e técnicas de tratamento e disposição final dos resíduos gerados em estações de tratamento de água. São Carlos: LDiBe, 2012. 540 p.

DI BERNARDO, L.; SCALIZE, P. S.; SOUZA FILHO, A. G. Água de lavagem de filtros rápidos. In: REALI, M. A. P. (coord.). Noções gerais de tratamento e disposição final de lodos de estações de tratamento de água. Rio de Janeiro: ABES, 1999.

FREITAS, J. G.; FERREIRA FILHO, S. S.; PIVELI, R. P. Viabilidade técnica e econômica da regeneração de coagulantes a partir de lodos de estações de tratamento de água. Eng. Sanit. Ambient., Rio de Janeiro, v. 10, n. 2 , p. $137-145,2005$.

FULTON, G. P. Recover alum to reduce waste-disposal costs. Journal AWWA, Denver v. 66, n.5, p. 312-318, 1974.

GONÇALVES, R. F.; BRANDÃO, J. T.; BARRETO, E. M. S. Viabilidade econômica da regeneração do sulfato de alumínio de lodos de Estações de Tratamento de Água. In: CONGRESSO BRASILEIRO DE ENGENHARIA SANITÁRIA E AMBIENTAL, 20, Rio de Janeiro, 1999. Anais [...]. Rio de Janeiro: [s. n.], 1999. p. 1298 - 1307.

IBGE - INSTITUTO BRASILEIRO DE GEOGRAFIA E ESTATÍSTICA Atlas de saneamento 2011. Rio de Janeiro: IBGE, 2011. 268 p.

IBGE - INSTITUTO BRASILEIRO DE GEOGRAFIA E ESTATÍSTICA. Disposição de resíduos de ETA. 2002. Available from: <https://www.ibge.com.br $>$. Access in: June 20, 2021.
JULIO, M; OROSKI, F.I; SANTOS, M. N. O; JULIO, T. S. Reuse of The Coagulant Recovered From WTP Sludge For Tertiary Treatment of Effluent of Stabilization Pond Preceded By Uasb Reactor. Revista DAE, São Paulo, 2010. DOI: http://doi.editoracubo.com.br/10.4322/dae.2014.072.

JUNG, K.; HWANG, M.; PARK, D.; AHN, K. Comprehensive reuse of drinking water treatment residuals in coagulation and adsorption process. Journal of Environmental Management, London, v. 181, p. 425-434, 2016.

KEELEY, J.; JARVIS, P.; JUDD, S. J. Coagulant recovery from water treatment residuals: a review of applicable technologies. Critical Reviews in Environmental Science and Technology, Boca Raton, v. 44, p. 2675-2719, 2014.

MASSCHELEIN, W. J.; DEVLEMINCK, R.; GENOT, J. The feasibility of coagulant recycling by alkaline reaction of aluminum hydroxide sludges. Water Research, Grã Bretanha, v. 19, n. 11, p. 1363-1368, 1985.

McCORMICK, N. J.; PORTER, M.; WALSH, M. E. Disinfection by-products in filter backwash water: implications to water quality in recycle designs. Water Research, New York, v. 44, p. 4581-4589, 2010.

OKUDA, T.; NISHIJIMA, W.; SUGIMOTO, M.; SAKA, N.; NAKAI, S.; TANABE, K.; ITO, J.; TAKENAKA, K.; OKADA, M. Removal of coagulant aluminum from water treatment residuals by acid. Water Research, New York, v. 60, p. $75-81,2014$.

RAJ, C. C.; KWONG, T. E.; WONG, CHENG; W. W., FONG; L. M., TIONG; S. H.; KLOSE, P. S. Wash water in waterworks: contaminants and process options for reclamation. Journal of Enviromental Sciences, China, v. 20, n. 11, p. 1300-13005, 2008.

REISSMANN, F. G.; UHL, W. Ultrafiltration for the reuse of spent filter backwash water from drinking water treatment. Desalination, Amsterdam, v. 198, n. 1/3, p. 225-235, 2006. DOI: 198. 225-235. 10.1016/j.desal.2006.03.517.

SAUNDERS, F. M.; ROEDER, M. L; Coagulant Recovery: a critical assessment. EUA: AWWA Research Foundation, 1991.

SILVA, F. A. S. Assistat. Versão 7.7 pt. [Campina Grande: Universidade Federal de Campina Grande], 2017. 1 Software. 
SLAVIK, I.; JEHMLICH, A.; UHL, W. Impact of backwashing procedures on deep bed filtration productivity in drinking water treatment. Water Research, New York, v. 47, p. 6348-6357, 2013.

USEPA - UNITED STATE ENVIRONMENTAL PROTECTION AGENCY. Drinking water treatment plant residuals. [S. l.; s. n.], Available from: <https://www. epa.gov/sites/production/files/2015-11/documents/dwtreatment-residuals-mgmt-tech-report-sept-2011.pdf $>$. Access in: 25 jun. 2021.
USEPA - UNITED STATE ENVIRONMENTAL PROTECTION AGENCY. Filter backwash recycling rule: technical guidance manual. [S. l.; s. n.], 2002.

WEBER, P; TORRES, T. L. Estudo para caracterização quantitativa e qualitativa lodo de estação de tratamento de água. In: CONGRESSO BRASILEIRO DE ENGENHARIA SANITÁRIA E AMBIENTAL, 24., 2007, Belo Horizonte. Anais [...]. Belo Horizonte, [s. n.], 2007. 